\title{
近赤外分光法による体脂肪測定
}

\author{
沢井史穂白山正人武藤芳照宮下充正
}

\section{ESTIMATION OF BODY FAT BY NEAR INFRARED SPECTROSCOPIC TECHNIQUE}

\author{
Shino Sawai, Masato Shirayama, Yoshiteru Mutoh \\ and Mitsumasa MiYashita
}

\begin{abstract}
Near infrared spectroscopy has been used to determine the chemical composition of food stuffs, i. e., the protein, fat, and moisture content. Recently in the U. S. A. this technique was applied to the estimation of human body composition, and a portable instrument was developed. This study was designed to determine the prediction equation of body fat for Japanese people. 69 men and 52 women, aged 18 to 58 years, covering a wide range of percent fat levels, physiques, physical activity levels, had body fat estimated by hydrostatic weighing (HW), skinfold thicknesses(SF) and near infrared spectroscopy. Near infrared interactance spectra were measured on the anterior midline of the biceps halfway (between the anticubital fossa and acromion), the spectral data from which gave best correlation with HW and SF compared the other sites, using the wavelength of $947 \mathrm{~nm}$. The spectral values and percent fat values obtained from $\mathrm{HW}$ about $1 / 2$ of subjects were used to develop a prediction equation. This equation was then used to predict $\%$ body fat of the other $1 / 2$ subjects. The correlation coefficient between $\%$ body fat as predicted by the near infrared method and as predicted by the HW technique was $0.88(\mathrm{p}<0.001, \mathrm{SEE}=3.2)$. This correlation value was similar to the value between $\%$ body fat as predicted by $\mathrm{HW}$ and as predicted by SF. In the American data, the correlation coefficients were higher when the other variables were added ; height, weight, age, but in the Japanese they did not almost change even when the other variables were added. There was not a difference between the spectra of right and left arm values. In the results, the prediction equation of $\%$ body fat for the Japanese population was determined as follows :

$\%$ body fat $=54.14-29.47 \times($ the spectral data at $947 \mathrm{~nm})[\mathrm{r}=0.88, \mathrm{p}<0.001, \mathrm{SEE}=3.2]$

(for right arm).
\end{abstract}

(Jpn. J. Phys. Fitness Sports Med. 1990, $39: 155 \sim 163$ )

key words: near infrared spectroscopy, body fat

\section{I. 鍺曹}

ヒトの身体組成には，個体差はもとより，性， 年龄, 人種, 実施している運動種目の違いによっ ても明らかな差が認められる $6,7,15,16,23,29,30)$. 身体 組成を測定することは，基本的情報として身体の 成分を知るといら意味に加え, 運動能力を筋量に 応じて正当に評価したり, 肥満の判定をしたりす
る上で有用である．しかし，生きたヒトの身体組 成を直接測定することは現在の測定技術では不可 能であるので，間接法を用いざるを得ない25)。現 在行われている主な測定法には，体密度法（水中 体重法 ${ }^{15,20)}$, 水置換法 $\left.{ }^{211}\right)$, 体水分法 $\left(\mathrm{D}_{2} \mathrm{O}\right.$ 法 ${ }^{18)}$, TOBEC 法 $^{241}, \mathrm{BIA}$ 法 $^{131}$ など)，体内カリウム法 ${ }^{31}$, 体内窒素法 ${ }^{171}$, 体内カルシウム法 ${ }^{21}$, クレアチニ ン法 ${ }^{16)}$ のほか, 局所の身体組成の測定として, 皮

東京大学教育学部体育学・スポーツ科学研究室 Laboratory for Exercise Physiology, Biomechanics and 于113 東京都文京区本郷7-3-1 


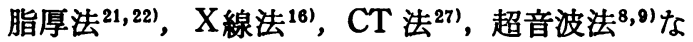
どがある.また，皮下脂肪厚や人体計測値から体 水分量や体密度を推定する予測式 ${ }^{14,21,28)}$ 。開発さ れている.これらの測定法それぞれに，西岡 ${ }^{221} の$ 挙げる測定方法としての条件, “妥当性（推定誤 差), 信頼性(測定者内䛊差), 客観性(測定者間誤 差)”を照らし合わせてみると，妥当性が高いと される方法は，大規模な設備や測定者の技術が必 要であるためにフィールドワークには不適当であ る. 一方, 皮脂厚法のような簡便な方法は, 妥当 性が低くなり，信頼性，客観性にも問題点が挙げ られるが，実用性，経済性には富んでいる。この ように各方法は長所, 短所を兼ね備兄ており, 最 適な測定方法を限定することは困難であるため, 測定の目的に応じて方法を選択・併用しているの が実状である.

ところで，近年 Conway $5^{3,4)}$ は近赤外分光法 をとトの体脂肪の測定に導入した，測定の原理 は, 有機化合物が近赤外域に特有の吸収帯を持つ ことを利用し，近赤外線を試料に照射したときの 吸収スペクトルを分析することにより，その物質 の組成を定性・定量化するというものである 2,10 , 11,19). 図1 亿示すよ5に，純粋な脂肪と水分はそ れぞれ $930 \mathrm{~nm}$ と $970 \mathrm{~nm}$ の波長に特有の吸收帯 を持ち，体脂肪の多い者は脂肪の吸収帯にスペク トルの大きなピーク值が現れている(図 2 )。そこ で，特定の身体部位における近赤外スペクトルを 得ることにより体脂肪率を推定しょうといら意図 で，携带用測定器がアメリカで開発された。この 測定器(FUTREX 社製 FUTREX-5000 TM)の妥 当性の検討は, アメリカの HUMAN PERFOR.



因 1。純粋な脂肪と水分から得た近赤外スペクトル (Conway, et al. 1984)
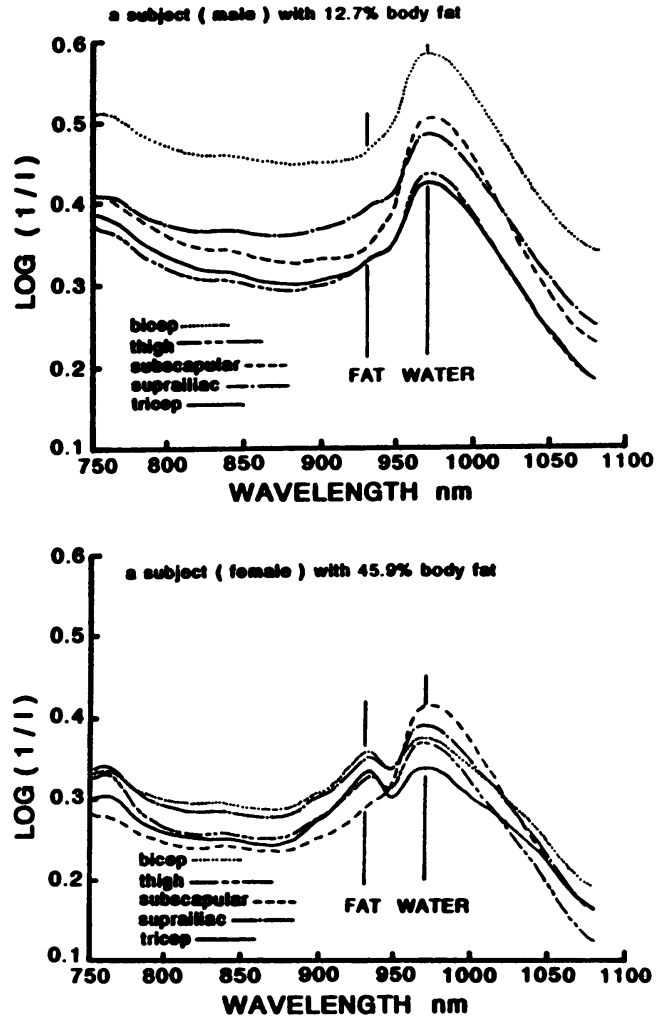

図2.体脂肪率の異なる被検者飞おける近赤外スぺ クトル (Conway, et al. 1984)

MANCE CENTER をはじめとして行われ，他の 身体組成測定法 $\left(\mathrm{D}_{2} \mathrm{O}\right.$ 法, 水中体重法, 皮脂厚法, 超音波法など) との高い相関（それぞれ，r=0.94， $0.85,0.86,0.84)$, 測定值の高い再現性 $(r=0.94)$ が報告されている゙．

ところで，この測定器は，体脂肪率の推定を行 らための回㷌式が，アメリカ人のデータに基つい たものであり，体格の異なる日本人の体脂肪率を 推定する場合，この式を当てはめることは適当で はない。

そこで，本研究の目的は，近赤外分光法による 携帯用体脂肪測定器を日本において沉用可能とす るための日本人用推定式を決定することである.

\section{II. 測定部位の検封}

Conway らは, 近赤外分光法による体脂肪の測 定部位を上腕二頭筋部, 上腕三頭筋部, 局甲骨下 部, 腸骨稜, 大腿前中央部の 5 ヶ所の皮虐表面と 
表 1. 測定部位の違いによる近赤外スペクトル值と体脂肪率との相関係数の比較

（ ）内は推定の標準誤差

\begin{tabular}{llccc}
\hline & & $\%$ fat $\left(\mathrm{D}_{2} \mathrm{O}\right)$ & $\%$ fat $(\mathrm{HW})$ & $\%$ fat (SF $)$ \\
\hline \multirow{2}{*}{$\mathrm{NIR}(870 \mathrm{~nm} / 945 \mathrm{~nm})$} & 5 ヶ所*の平均 & $0.90(3.2)$ & $0.85(4.3)$ & $0.82(3.9)$ \\
& 上腕二頭笳部十上腕三頭筋部 & $0.90(3.2)$ & $0.87(4.2)$ & $0.82(3.9)$ \\
& 上腕三頭笳部 & $0.88(3.5)$ & $0.84(4.5)$ & $0.84(3.7)$ \\
& 上腕二頭筋部 & $0.90(3.2)$ & $0.89(3.8)$ & $0.81(4.0)$ \\
\hline
\end{tabular}

* 上腕二頭筋部，上腕三頭笳部，肩甲骨下部，腸骨稜，大腿中央部

(Conway, et al. 1984)

し，その部位からの近赤外スペクトルと $\mathrm{D}_{2} \mathrm{O}$ 法, 水中体重法, 皮脂厚法による体脂肪率との相関を 調べた．その結果，表 1 に示したように，全身の 体脂肪推定法として妥当性が高いと考えられる $\mathrm{D}_{2} \mathrm{O}$ 法及び水中体重法と最も相関が高かった部 位は，上腕二頭筋部であった，そこで本研究にお いては，まず，測定対象を日本人とした場合も同 様の結果が得られるかどらかを検討した。

\section{A. 方 法}

被検者は, 20４4歳の健常な男性28名，女性18 名であり, 測定に先立って, 研究の目的, 方法, 意義, 危険性等を説明し, 被検者として参加する ことに対する同意を得た。

8 ヶ所の身体部位（上腕二頭筋部, 上腕三頭筋 部, 肩甲骨下部, 胸部, 腹部, 腸骨稜, 大腿前中 央部, 腓腹筋部の皮虐表面）を測定対象に選び， 各々の部位に近赤外分光を照射し，そこからの光 吸収スペクトルを測定した。測定器は, FUTREX 社製 FUTREX-5000TM の日本バージョンであ る物ケット科学研究所製 FITNESS ANALYZER BFT-2000 を用いた(図 3 ). 測定システムを図 4

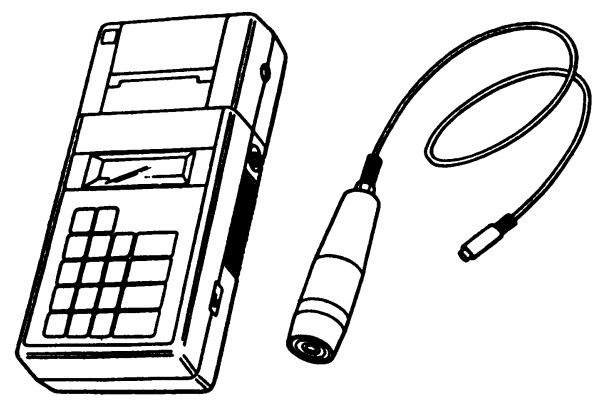

図 3.科学研究所製 FITNESS ANALYSER BFT-2000

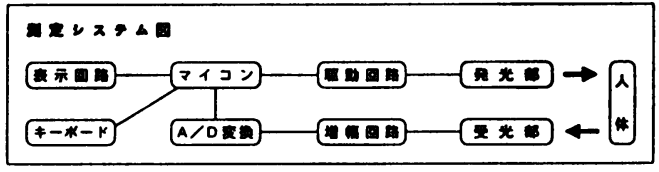

図 4. FITNESS ANALYSER BFT-2000 の測定シ ステム図

に示す. まず，予め標準体(テフロンブロック)に よってキャリブレーションを行ったプローブを測 定部位に当て, 異なる 2 波長の近赤外線を照射し た. 照射光の波長は, 測定器をフィールドワーク 用に小型で低コストに抑えるためにななるべく近 い波長域で脂肪と水分とにそれぞれ大きな吸収ス ペクトルが得られる $937 \mathrm{~nm}$ (脂肪吸収帯付近) と $947 \mathrm{~nm}$ (水分吸収带付近)が選択された。 そして, 得られたそれぞれの波長に打ける吸収スペクトル は $\log \mathrm{l} / \mathrm{I}(\mathrm{I}:$ Interactance $)$ に変形され, 標準体か ら得た吸光度に対する割合として計算された。測 定にあたっては, 外部の光線の侵入を防ぎ, プロ ーブを測定部位に垂直に当てることができるよう なバンドを装着した上で，プローブを押しあてて 近赤外線を照射した(図 5 ).

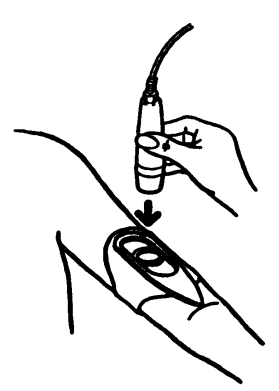

図 5. 測定部位と近赤外線を効果的に照射させるた めのパンド 
体脂肪率の指標となる値は，水中体重法による 測定值を採用した。水中体重は, $10 \mathrm{~g}$ 単位で測定 し，2〜3 回測定したらち, 最も高い值を測定値 とした，残気量の測定は，酸素再呼吸法を用い， 頸部まで水中に沈めた状態で，呼気ガス中の窒素 濃度の安定した值が得られるまで測定を繰り返し た。

\section{B. 結果及び考㝝}

被検者特性は表 2 に示した. Conway らは, 体 脂肪率の推定式を決定する際， 2 波長の近赤外ス ペクトル值 $(\log 1 / \mathrm{I})$ の比をとって独立変数として いたが，日本人を対象とした本研究の結果は，2

表 2。被梚者特性

\begin{tabular}{|c|c|c|c|}
\hline & & $\begin{array}{c}\text { 男 性 } \\
\text { 平均 } \mathrm{SD} \\
(\text { VV }\end{array}$ & $\begin{array}{c}\text { 女性 } \\
\text { 平均 } \pm \text { SD } \\
\text { (レンジ) }\end{array}$ \\
\hline 人 & 数 & 28 & 18 \\
\hline 年 & 齡(歳) & $\begin{array}{c}24.4 \pm 6.7 \\
(20 \sim 44)\end{array}$ & $\begin{array}{r}23.8 \pm 5.5 \\
(20 \sim 39)\end{array}$ \\
\hline 身 & 長 $(\mathrm{cm})$ & $\begin{array}{l}170.6 \pm 4.6 \\
(161.2 \sim 177.8)\end{array}$ & $\begin{array}{l}158.6 \pm 5.4 \\
(149.1 \sim 169.5)\end{array}$ \\
\hline 体 & 重(kg) & $\begin{array}{c}63.4 \pm 7.8 \\
(49.1 \sim 88.6)\end{array}$ & $\begin{array}{l}51.9 \pm 3.8 \\
(44.2 \sim 63.2)\end{array}$ \\
\hline \multicolumn{2}{|c|}{$\begin{array}{l}\text { 体脂肪率 }(\%) \\
\text { (水中体重法による) }\end{array}$} & $\begin{array}{l}13.7 \pm 5.0 \\
(5.7 \sim 32.0)\end{array}$ & $\begin{array}{l}21.5 \pm 4.2 \\
(11.4 \sim 28.5)\end{array}$ \\
\hline
\end{tabular}

表 3.異なる部位における近赤外スペクトル值と 体脂肪率との相関係数

（ )内は推定の標準誤差

\begin{tabular}{|c|c|c|}
\hline 測 定 部 位 & 水中体重法 & 皮脂厚法 \\
\hline 上腕二頭笳部 & $0.89(2.8)$ & $0.87(3.3)$ \\
\hline 上腕三頭笳部 & $0.78(3.9)$ & $0.65(5.0)$ \\
\hline 肩甲骨下部 & $0.72(4.3)$ & $0.56(5.5)$ \\
\hline 胸 部 & $0.85(3.2)$ & $0.76(4.3)$ \\
\hline 腹 部 & $0.77(3.9)$ & $0.55(5.6)$ \\
\hline 腸骨稜 & $0.82(3.6)$ & $0.72(4.6)$ \\
\hline 大腿部 & $0.79(3.8)$ & $0.67(4.9)$ \\
\hline 下腿部 & $0.79(3.8)$ & $0.78(4.2)$ \\
\hline 上腕二頭筋部＋上腕三頭筋部 & $0.91(2.7)$ & $0.87(3.4)$ \\
\hline 上腕二頭筋部＋肩甲骨下部 & $0.91(2.7)$ & $0.87(3.3)$ \\
\hline 上腕二頭笳部＋胸部 & $0.90(2.8)$ & $0.88(3.3)$ \\
\hline 上腕二頭筋部+腸骨稜 & $0.90(2.7)$ & $0.88(3.2)$ \\
\hline 上腕二頭筋部＋胸部＋腸骨稜 & $0.91(2.7)$ & $0.89(3.2)$ \\
\hline 全測定部位の合計 & $0.92(2.9)$ & $0.91(3.3)$ \\
\hline
\end{tabular}

波長のスペクトル值がきわめて近似した值を示し たため, 比をとらず各々の值を独立变数として水 中体重法から求めた体脂肪率との相関を調べた. 表 3 がその結果である. 各部位とも水中体重法に よる体脂肪率の值と高い相関が得られたが, 最も 相関が高かった測定部位は Conway らの報告と 同様上腕二頭笳部であり，測定部位を增やしても 相関係数に明らかな向上は認められなかった．上 腕二頭筇部は，そこからの近赤外スペクトルだ で全身の体脂肪率と高い相関が得られたことに加 え，被㭘者自身がプローブをあてて測定すること ができる部位であるという利点を持っており，日 本人に打いても本測定法の測定部位として上腕二 頭筋部が適当であろらと考えられた。

\section{III. 日本人用推定式の開発}

\section{A. 方 法}

年龄，体格，身体運動レベルが異なる18～58歳 の健常な男性 67 名，女性52名を被検者とした。測 定に先立って, 研究の目的, 方法, 意義, 危険性 等を説明し，被検者として参加することに対する 同意を得, 身長, 体重, 近赤外スペクトルを測定 した. その際の近赤外線の照射部位は, 前述の結 果に基づき，上腕二頭筋部（肩峰と时窝の中点に あたる皮膚表面）とし，左右両腕とも測定を行っ た。体脂肪率の指標は水中体重法による測定值を 用い，また一般に最も利用されている皮脂厚法と も比較を行った。

皮脂厚法は，栄研式皮脂厚計を用い，右上腕背 部，右肩甲骨下部の 2 点を測定部位とし，長嶺ら の式 ${ }^{21}$ 及び Brožek らの式" から体脂肪率を推定 した.

身長, 体重, 皮脂厚法, 近赤外分光法による体 脂肪の測定は，検者間の測定誤差の影響を防ぐた めに, 同一検者が行った.

身体運動レベルについての調查も行い, 被検者 各自が測定用紙に記入した，身体運動レベルは, 速く歩くかそれと同様の運動を行う時間が，一日 平均 1 時間以上ある場合は HEAVY (0.08 点), 30 分以上の場合は MODERATE(0.05 点), 15分以上 の場合は LIGHT (0.02点), それ以下の場合は 
OTHER $(0.00$ 点) として段階分けし, 得点化した. $937 \mathrm{~nm}$ と $947 \mathrm{~nm}$ の 2 波長の近赤外線に対す る測定部位からの光吸収スペクトル值は，それぞ れ平均 $1,252,1,274$ で，水中体重法による体脂肪 率との相関係数はそれぞれ $-0.878 ，-0.883$ であ った。このことから，本測定で用いた 2 波長は， いずれる日本人を対象とした場合，測定部位にお ける光吸収スペクトル值にほとんど差がみられ ず, 1 波長だけで体脂肪率の推定が可能であろう と予想された。 そこで，近赤外分光法による体脂 肪率の推定式の決定に当たっては, やや相関係数 の值が高かった $947 \mathrm{~nm}$ の近赤外スペクトル值 (NIR) を独立变数とし, 水中体重法から求めた体 脂肪率の值を従属变数として回帰分析を行った. また，近赤外スペクトル值に他の情報を加えた以 下の 3 通りの独立変数による重回煗分析も行っ た.

1. NIR, 身長, 体重

2. NIR，身長，体重，年齡

3. NIR, 身長, 体重, 年夦, 身体運動レベル 各推定式は，無作為に抽出した全被検者の $1 / 2$ の測定値を使って算定した．そして，残り $1 / 2$ の 被検者のデータをその式に代入して得た体脂肪率 の推定值と, 同一被検者の水中体重法から求めた 体脂肪率の值との相閔を調べた.

\section{B. 結 果}

被検者の特性は，表 4 の通りであった，NIR と 水中体重法による体脂肪率 ( $\mathrm{HW}$ ), 皮脂厚法によ る体脂肪率 (SF) との相関は, 表 5 の通りであっ

表 4。被検者特性

\begin{tabular}{|c|c|c|c|}
\hline & & $\begin{array}{c}\text { 男 性 } \\
\text { 平均 } \pm \text { SD } \\
\text { (レンジ) }\end{array}$ & $\begin{array}{c}\text { 女性 } \\
\text { 平均 } \pm \text { SD } \\
(\text { レンジ) }\end{array}$ \\
\hline 人 & 数 & 67 & 52 \\
\hline 年 & 龄(歳) & $\begin{array}{c}28.5 \pm 12.7 \\
(18 \sim 58)\end{array}$ & $\begin{array}{c}30.6 \pm 11.8 \\
(18 \sim 56)\end{array}$ \\
\hline 身 & 長 $(\mathrm{cm})$ & $\begin{array}{c}170.7 \pm 6.1 \\
(158.6 \sim 184.5)\end{array}$ & $\begin{array}{l}157.9 \pm 5.4 \\
(143.7 \sim 170.8)\end{array}$ \\
\hline 体 & 重 $(\mathrm{kg})$ & $\begin{array}{c}65.2 \pm 7.3 \\
(49.9 \sim 83.1)\end{array}$ & $\begin{array}{c}51.9 \pm 5.2 \\
(41.3 \sim 65.3)\end{array}$ \\
\hline \multicolumn{2}{|c|}{$\begin{array}{l}\text { 体脂肪率 (\%) } \\
\text { (皮中重法による) }\end{array}$} & $\begin{array}{l}14.1 \pm 5.2 \\
(5.1 \sim 28.1)\end{array}$ & $\begin{array}{c}23.7 \pm 4.6 \\
(14.8 \sim 33.9)\end{array}$ \\
\hline
\end{tabular}

表 5. 近赤外スペクトル值 (NIR) と水中体重法 (HW)ならびに皮脂厚法 $(\mathrm{SF})$ 飞よる体脂肪率 との相関

（ ）内は推定の標準誤差

\begin{tabular}{lcc}
\hline & $\%$ fat $(\mathrm{HW})$ & $\%$ fat $(\mathrm{SF})$ \\
\hline $\mathrm{NIR}(947 \mathrm{~nm})$ & $-0.88(3.2)^{* * *}$ & $-0.82(3.9)^{* * *}$ \\
$\%$ fat $(\mathrm{HW})$ & - & $0.87(3.4)^{* * *}$ \\
\hline & & $* * *: \mathrm{p}<0.001$
\end{tabular}

た.すなわち, NIR と HW, SF との間には高い負 の相関が㸾められた。 そこで, 光吸収スペクトル の值 $(\log 1 / \mathrm{I})$ をW の值に回㷌させ，推定式を 求めた. ただし，推定値と HW による值との䛊 差の検証を行うため, 推定式は全体の $1 / 2$ のデー タに基づいて算定した，その結果得られた式は，

体脂肪率 $=54.91-28.35 \times(\mathrm{NIR})$

$$
\begin{aligned}
& {[r=0.88(p<0.001), S E E=3.0] \text { (右腕) } \cdots \cdots .(1)} \\
& \text { 体脂肪率 }=50.82-25.74 \times(\mathrm{NIR}) \\
& \{r=0.88(p<0.001), \mathrm{SEE}=3.0\} \text { (左腕) } \cdots \cdots(1)^{\prime} \\
& \text { ( } \mathrm{SEE}: \text { 推定の標準誤差) }
\end{aligned}
$$

であった。

そしてそれぞれの式に残り $1 / 2$ の被検者の NIR のデータを代入して求めた体脂肪率の推定值と水 中体重法によって得た体脂肪率との相関を調べた ところ, 表 6 に示したように NIR のデータのみ

表 6. NIR に他の变数を加えた場合の水中体重法 との相関

（ ）内は推定の標準誤差

\begin{tabular}{cc}
\hline$€$ デ ル & 相関係数 $(\mathrm{see})$ \\
\hline $\mathrm{NIR}(947 \mathrm{~nm})$ & $0.89(2.9)^{* * *}$ \\
+身長+体重 & $0.90(2.9)^{* * *}$ \\
十身長+体重+年齢 & $0.91(2.7)^{* * *}$ \\
十身長十体重+身体活動量 & $0.90(2.9)^{* * *}$ \\
\hline & $* * *: \mathrm{p}<0.001$
\end{tabular}

を独立変数としたモデル式を用いた場合， $\mathrm{r}=0.89$ $(\mathrm{SEE}=2.9)$ の高い相関が得られ, 他の变数を独立 変数に加えたモデル式を用いても相関係数の值は ほぼ同様であった．この結果は左右の腕で差がな かった. (1)式を用いて推定した体脂肪率と HW か ら求めた体脂肪率との関係を示したのが図 6 であ 


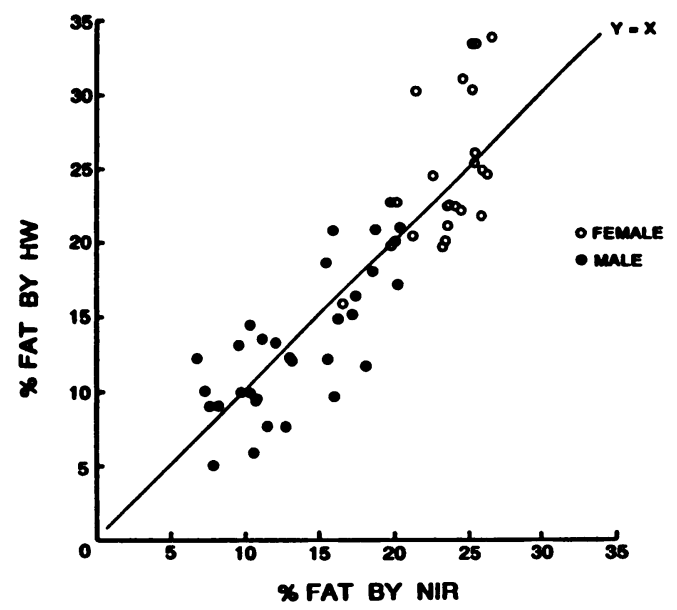

図6. 近赤外分光法によって推定した体脂肪率と水 中体重法によって求めた体脂肪率との関係

る. 近赤外分光法では, 体脂肪率の高い一部の女 性に過小評価が見られるものの，全体的にはHW とほぼ近似した結果が得られていた。

以上の結果から，近赤外分光法による日本人用 体脂肪率推定式は,

体脂肪率 $=56.14-29.47 \times(\mathrm{NIR}: 947 \mathrm{~nm})$

$\{r=0.88(p<0.001), \mathrm{SEE}=3.2\}$ (右腕

と決定された。

(2)式を用いて求めた体脂肪率と他の推定法によ る体脂肪率の平均値をそれぞれ表 7 に示したが， 全ての平均値が非常によく一致した.

\section{IV.}

本研究の被検者群は，表 4 を見て分かるように， 年龄，体格がさまざまなタイプの日本人男女から 構成されていた.1989年の厚生省「国民衛生の動 向 ${ }^{12}$ によると，本研究の被検者の平均年龄にあ たる年龄の身長の平均値は, 男性 $169.8 \pm 6.1 \mathrm{~cm}$, 女性 $156.3 \pm 4.9 \mathrm{~cm}$, 平均体重は, 男性 $64.3 \pm 9.5 \mathrm{~kg}$,

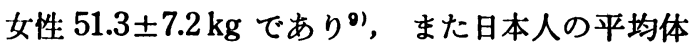
脂肪率は，男性が約 $15 \%$ ，女性が約 $25 \%$ とされて いる ${ }^{19}$ が, 本研究の被検者の平均値もそれらとほ ぼ同様の值を示していた．したがって，本研究の 被検者群は，日本人を代表する標本集団として適 当とみなしてょいであろう.

上腕二頭筇部での近赤外線の吸光度と, 体脂肪 率との間に高い負の相関 $(\mathrm{r}=-0.88, \mathrm{SEE}=3.2)$ が 認められたことは，この測定部位に打ける近赤外 スペクトルがヒトの体脂肪率を反映する指標たり らることを示している. そこで, 無作為抽出した $1 / 2$ の被検者について，近赤外線吸収スペクトル の值 $(\log 1 / \mathrm{I})$ を水中体重法による測定値に回㷌 させ, 体脂肪率の推定式を得た. そして, 残り $1 / 2$ の被検者の NIR のデータをこの式に代入して推 定した体脂肪率の值と，実際に水中体重法で求め た体脂肪率の值とを比較したところ, Conway ら の報告同様 ${ }^{2,3}$, 高い相関 $(\mathrm{r}=0.89, \mathrm{p}<0.001$, $\mathrm{SEE}=2.9$ ) が認められた.

一方, 彼らは推定式を決定するにあたって，独 立变数に NIR の他, 体重, 性, 身長のパラメタ 一を加えていくにしたがい，相関係数の值が高く なったことを示した $(r=0.72 か ら ~ r=0.90$ 向上 $)$ が, 本研究では, 近赤外スペクトル值たけで体脂 肪率との高い相関を示し，それ以外のパラメター を説明変数として加えても相関係数に明らかな向 上はみられなかった。このことから，日本人にお いて近赤外分光法による体脂肪率の推定を行う際 は, 近赤外線の吸光度以外の情報をあえて入力す る必要性は特にないと考えられる. また，左右ど ちらの上腕を測定部位にしても，結果に差はみら れなかったことから，どちらのデータに基づいた 推定式を用いてもよいといえよう．したがって， 近赤外分光法による日本人用体脂肪率 の 推 定 式

表 7. 異なる推定法で求めた体脂肪率の此較

\begin{tabular}{|c|c|c|c|c|c|c|c|c|c|}
\hline & \multicolumn{3}{|c|}{ 近赤外分光法 } & \multicolumn{3}{|c|}{ 水中体重法 } & \multicolumn{3}{|c|}{ 皮脂 厚法 } \\
\hline & 男性 & 女性 & 全体 & 男性 & 女性 & 全体 & 男性 & 女性 & 全体 \\
\hline 平均 $(\%)$ & 14.7 & 23.2 & 18.6 & 14.3 & 23.8 & 18.6 & 14.4 & 23.5 & 18.6 \\
\hline SD & 4.8 & 3.8 & 6.1 & 5.3 & 4.6 & 6.9 & 4.6 & 6.5 & 7.2 \\
\hline
\end{tabular}


表 8. 近赤外分光法 (NIR) と水中体重法 (HW) ならびに皮脂厚法 (SF) とよる体脂 肪率との相関係数

（ )内は推定の標準誤差

\begin{tabular}{cccccccc}
\hline & \multicolumn{3}{c}{ \%fat (HW) } & & \multicolumn{3}{c}{$\%$ fat (SF) } \\
\cline { 2 - 3 } \cline { 7 - 8 } & 男 性 & 女 性 & 全 体 & & 男性 & 女 性 & 全 体 \\
\hline \%fat(NIR) & $0.82(3.1)$ & $0.70(3.3)$ & $0.88(3.2)$ & & $0.82(2.5)$ & $0.61(5.0)$ & $0.82(3.9)$ \\
\%fat(HW) & & - & & & $0.78(3.3)$ & $0.79(2.8)$ & $0.87(3.4)$ \\
\hline
\end{tabular}

は，(2)式に決定された.

また，男女別に近赤外分光法と他の推定法によ る体脂肪率との相関係数(表 8 )を見ると，男性に 比べ女性の方が相関が低く，女性の場合近赤外分 光法による体脂肪率の推定精度は男性より劣る可 能性が予想される。このような男女間の違いは Conway らの結果にも現れていたことから，男女 別推定式の必要性が考えられるが，それには男女 それぞれ，より広範囲の体脂肪率を有する被検者 群からのデータを収集する必要があろう.

近赤外分光法による体脂肪測定は，前述したよ うな測定法としての条件に照らしてみると，局所 的な体脂肪量を反映する指標から全身の体脂肪率 を推定しているために，推定誤差が生じ易く，妥 当性においては皮脂厚法と共通するところが大き いと考兄られる. 実際, 近赤外分光法と水中体重 法との相関は, 皮脂厚法と水中体重法との相関と ほぼ同様であった。したがって, 近赤外分光法は 測定精度では皮脂厚法程度は十分期待できると考 えられる.しかる，皮脂厚法の持つ測定上の欠点 （測定者の熟練が必要であること，キャリパーの あて方，皮膚のつまみ方による測定誤差が生じ易 いこと，測定者間䛊差が大きいこと22,26)，瘦せ， 肥満者の測定には不適当であること ${ }^{3,26) ， 人 に よ ~}$ っては皮膚をつままれて不快感を感じることな ど）を補っており，その上測定部位が一ヶ所で済 み，検者なしに自分自身で簡単に測定を行うこと ができるといら利点を持っていることから，多数 の対象を測定する場合に実用的な方法であると思 われる。

本研究の結果, 近赤外分光法による体脂肪の測 定法はフィールドワーク用として有効であること が確認され，日本人用の推定式が開発されたこと
により，今後，本測定法の日本における広い汎用 が可能となったといえよう.

\section{V. 要 約}

近赤外分光法は, 従来, 食品成分の非破壊分析 法として用いられてきたが，近年アメリカにおい てこの方法をヒトの体脂肪率の推定に応用する試 みがなされ，携帯用小型測定器が開発された．本 研究は，この測定法を日本においても汎用可能と するための日本人用体脂肪率推定式を決定しょう とするすのである. 年龄, 体格, 身体活動量の異 なる18〜58歳の健常な男性69名，女性52名を対象 に，身長，体重，体脂肪率を測定した，体脂肪率 は, 水中体重法, 皮脂厚法, 近赤外分光法の 3 方 法を用いて推定した. 近赤外分光法の 測 定 部位 は, 予備実験の結果, アメリカにおける先行研究 と同様, 他の測定法による体脂肪率との相関が最 も高かった上腕二頭筋中央部とし，947 nm の近 赤外線を照射して光吸収スペクトルを得た．被検 者の $1 / 2$ につて，それぞれの近赤外スペクトル の値を水中体重法による体脂肪率に回㷌させ，体 脂肪率推定式を算出した. 残り $1 / 2$ の被検者の近 赤外スペクトルをその式に代入して得た体脂肪率 と水中体重法によって求めた体脂肪率の值とを比 較したところ，r=0.89 (SEE=2.9) の高い相関が 認められた.これは，水中体重法と皮脂厚法との 間の相関俰数とほぼ同様の值であった. アメリカ 人用の推定式の決定には, 近赤外分光法スペクト ルの他に身長, 体重, 年龄の変数を加えた方が, 相関係数の值が高くなったと報告されているが， 日本人の場合, 他の変数を加えても相関係数の值 はほとんど変わらなかった。 また，測定部位にお ける左右差はなかった，したがって，近赤外分光 
法による日本人用体脂肪率の推定式は, 体脂肪 率 $=54.14-29.47 \times(947 \mathrm{~nm}$ における近赤外ス ゚゚ クトル値 $)\{\mathrm{r}=0.88(\mathrm{p}<0.01), \mathrm{SEE}=3.2\}$ と決定さ れた。

本研究は, 淘ケット科学研究所奖学寄付金により行わ れた.

本研究の一部は, (社)日本食品工業学会主催非破壊計 測シンポジウム (1988年11月, 東京) において発表され た.

（受付 昭和63年12月21日）

\section{考文献}

1) Brožek, J., F. Grande, J. T. Anderson, and A. Keys (1963) : Densitometric analysis of body composition: Review of some quantitative assumptions. Ann. N. Y. Acad. Sci., 110, 113-140.

2) Buskirk, E. R.(1987) : Body composition analysis : the past, present and future. Res. Quart.,58(1), 110.

3) Conway, J. M., Norris, K. H. and Bodwell, C. E. (1984) : A new approach for the estimation of body composition : infrared interactance. Am. J. Clin. Nutr., 40, 1123-1130.

4) Conway, J. M. and Norris, K. H. (1986) : Noninvasive body composition in humans by near infrared interactance. Ellis, K. J., Yasumura, S., and Morgan, W. D. In vivo body compositopn studies, Ed., proceedings of international symposium held at Brookhaven National Laboratory, New York published by the Institute of Physical Sciences in Medicine, London, 163-170.

5) Davis, P. O. and Paynter, L. (1988) : Technical note: Evaluation of a commercial near-infrared instrument for body composition analysis. Gai. thersburg, MD : Futrex Inc.

6) Forbes, G. B. (1987) : Human body composition growth, aging, nutrition, and activity. Ed., Springerverlag New York Inc.

7) 福永哲夫, 湯浅固元(1986)：コーチングの科学. 朝 合書店, 東京, 98-100.

8）福永哲夫(1987)：エコーによる肥満の測定. 臨床ス ポーツ医学, 4(3), 291-298.
9）石田良恵，福永哲夫(1986)：超音波 B mode 法によ る皮下脂肪厚の測定. ヤシロダ健康体力研究所報, $1(3), 2-5$.

10）岩元睦夫(1980)：近赤外分光法による食品成分の非 破壊測定. 日本食品工業学会誌，27(9)，464-472.

11）岩佐睦夫, 魚住 純(1985): 近赤外分光法による食 品成分の非破壊測定一最近の動向一. 日本食品工業 学会誌, 32(9), 685-695.

13. (財) 厚生統計協会 (1989)：国民衛生の動向・厚生の 指標. 臨時增刊, 36(9), 447.

13) Jackson, A. S., Pollock, M. L., Graves, J. E. and Mahar, M. T.(1988) : Reliability and validity of bioelectrical impedance in determining body composition. J. Appl. Physiol., 64, 529-534.

14) Johnston, F. E.(1982) : Relationship between body composition and anthropometry. Human Biol., 54, 221-245.

15) Himes, J. H. (1988) : Racial variation in physique and body composition. Can. J. Spt. Sci., 13, 117126.

16）小宮秀一，佐藤方彦，安河内朗(1988)：体組成の科 学. 朝倉書店, 東京, 21 .

17) Lukaski, H. C.(1987): Method for the assessment of human body composition : traditional and new. Am. J. Clin. Nutr., 46, 537-556.

18) Lukaski, H. C. and Johnson, P. E.(1985) : A simple, inexpensive method of determining total body water using a tracer dose of $\mathrm{D}_{2} \mathrm{O}$ and infrared absorption of biological fluids. Am. J. Clin. Nutr., 41, 363-370.

19）間宮真佐人(1976)：個体の吸収スペクトル測定法第 2 講. 払散反射法, 分光研究, 25(2), 99-117.

20）宮下充正(1986)：一般人・スポーツ選手のための体 力診断システム、ソニー企業的，東京，56.

21) Nagamine, S. and Suzuki, S.(1964) : Anthropometry and body composition of Japanese young men and women. Human Biol., 36, 8-15.

22）西岡伸紀(1984)：皮下脂肪厚の測定について一キャ リパーによる測定を中心に一. 体有の科学, 34, 535538.

23）小野三嗣(1988)：肥満のスポーツ医学. 朝倉書店, 東京, 27-40.

24) Presta, E., Wang, J., Harrison, G. G., Bjorntorp, P., Harker, W. H. and Van Itallie, T. B. (1983) : 
Measurement of total body conductivity : a new method for estimation of body composition. Am. J. Clin. Nutr., 37, 735-739.

25）体育科教育研究会編 (1981): 体育学実験 - 演習概説. 大修館書店, 東京, 46 .

26) 高本美和子(1986)：肥満の測定法. Jpn. J. Sports Sci., 5(11), 774-782.

27）徳永勝人，松沢侑次 (1987)：CT による肥満の測定. 臨床スポーツ医学, 4(3), 299-305.

28) Wilmore, J. H. and Behnke, A. R.(1969) : An anthropometric estimation of body density and lean body weight in young men. J. Appl. Physiol., 27, 25-31.
29) Withers, R. T., Whittingham, N. O., Norton, K. I., Forgia, J. L., Ellis, M. W. and Crockett, A.(1987) : Relative body fat and anthropometric prediction of body density of female athletes. Eur. J. Appl. Physiol., 56, 169-180.

30) Withers, R. T., Craig, N. P., Bourdon, P. O. and Norton, K. I.(1987) : Relative body fat and anthropometric prediction of body density of male athletes. Eur. J. Appl. Physiol., 56, 191-200.

31) 吉沢康雄, 今堀 章, 上田慶子, 田所美枝子(1968)： 小児の全身カリウム量の年龄, 身長による変化. 日 本小児科学会雑誌, 72, 109-114. 